\title{
Transatlantica
}

Revue d'études américaines. American Studies Journal

2 | 2014

Aesthetics of Theory in the Modern Era and Beyond / Photographie documentaire

\section{Robert M. Thorson, Walden's Shore: Henry David Thoreau and Nineteenth Century Science}

\section{Sarah Luria}

\section{(2) OpenEdition}

\section{Journals}

Electronic version

URL: https://journals.openedition.org/transatlantica/7099

DOI: $10.4000 /$ transatlantica.7099

ISSN: $1765-2766$

Publisher

Association française d'Etudes Américaines (AFEA)

Electronic reference

Sarah Luria, "Robert M. Thorson, Walden's Shore: Henry David Thoreau and Nineteenth Century Science", Transatlantica [Online], 2 | 2014, Online since 05 March 2015, connection on 02 February 2023. URL: http://journals.openedition.org/transatlantica/7099 ; DOl: https://doi.org/10.4000/transatlantica.7099

This text was automatically generated on 2 February 2023.

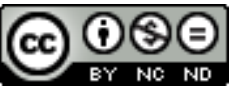

Creative Commons - Attribution-NonCommercial-NoDerivatives 4.0 International - CC BY-NC-ND 4.0

https://creativecommons.org/licenses/by-nc-nd/4.0/ 


\title{
Robert M. Thorson, Walden's Shore: Henry David Thoreau and Nineteenth Century Science
}

\author{
Sarah Luria
}

\section{REFERENCES}

THORSON, Robert M., Walden's Shore: Henry David Thoreau and Nineteenth Century Science, Harvard University Press, 2013, 440p., ISBN: 978-0674724785, \$ 27

1 Humanist scholarship has become increasingly focused on the scientific nature of Thoreau's writings. Happily several research scientists today are affirming the importance and scope of Thoreau's work. Botanist Richard Primack uses the data on seasonal change collected by Thoreau and his Concord neighbors to chart global warming in the region over a span of more than 150 years. Now we are fortunate to have geologist Robert M. Thorson's Walden's Shore: Henry David Thoreau and NineteenthCentury Science (Harvard University Press, 2013), which makes a persuasive case for Thoreau as a physical scientist. Thorson argues that Thoreau's deep engagement with geology, and its importance to Walden, has been largely overlooked: "Thoreau wrote about...soil mechanics, rock mechanics, fluid mechanics...with a joie de vivre equal to [that] he used to describe plants and animals" (130-31). In Thorson's view, Thoreau's understanding of the geodynamics that formed his landscape was not only “astonishingly accurate" at times (xv), but "presciently...correct" (84).

2 Robert Thorson is a rare find: a research scientist who is interested in American Studies approaches to Thoreau. A professor of geology at the University of Connecticut, Thorson places himself in the "embryonic" field of "cultural geology," which "seeks to understand American culture through [geology's] traditional disciplinary lens" (14). Thorson has read and re-read Walden with literary scholars and historians, including Wayne Franklin and Robert Gross, and co-taught courses such as "Walden and the 
American Landscape." Thorson's impressive survey of ecocriticism on Thoreau leads him to conclude that it has been too "biocentric" in its approach. It is time we expanded our focus to a "geo-criticism" able to attend to what Thorson persuasively argues was Thoreau's immersion in the debates forming the still young field of geology in his day. Thorson's thesis, as he says, is "simple": "paying attention to Thoreau's rocks and minerals raises new possibilities for interpretation" $(14 ; 260)$. More broadly Thorson faults the "recent trend in ecocriticism" that "refracts science through literature without being scientific" and produces "an almost purely descriptive literature" (11). Just what Thorson means here becomes apparent as we read his book, which shows what a scientific eco-, or rather geocriticism looks like.

Thorson's project is to reconstruct a genealogy of Thoreau's geological ideas by reading everything Thoreau wrote up until the time he published Walden in 1854. Thorson's method is impressive: he has made a "concordance spreadsheet" to track Thoreau's discussion of geology in his Journals and other concurrent writings, to see what echoes might be found in Walden. Thorson further situates Thoreau's writings in the context of his reading-for example, when Thoreau read Lyell's Principles of Geology (which Emerson recommended to him), and Hitchcock's History of Massachusetts (which offered an account of geological formation that accorded with biblical theology). Of particular interest to Thorson is the two-year hiatus Thoreau took in 1850 from working on Walden. During that time Thoreau read Darwin's Journals. These years, Thorson maintains, caused Thoreau to "upgrade" Walden into a much more scientifically informed study. Thorson allows that Thoreau discussed geology at length in his Journals, but often only "covertly" in Walden: "the informing scientific content for most Walden passages survives in the Journal as fragments that can be pieced together if one knows what to look for" (13).

4 Thorson's concordance approach leads to new insights on Walden, such as in the famous passage in the "Economy" chapter when Thoreau throws the pieces of limestone on his desk out the window. Thoreau cites this as an act of simplifying his life: the rock collection required work to dust. But Thorson's concordance approach seizes upon Thoreau's specification that the rocks were "limestone" to connect it to his mentioning in chapter 13, "Higher Laws," that he knew how to make limestone himself. By Thorson's reconstructive reading of such "clues," the pieces of limestone perhaps disgusted Thoreau as a reminder of "his failure to be self-reliant." Rather than make his own limestone for his house Thoreau paid, as his list of expenses in "Economy" states, “\$2.40 for two casks of manufactured lime," which Thoreau complains "was high." Thorson's purpose is not to insist upon his speculative interpretation of the meaning of the limestone, but to show how "paying attention to Thoreau's rocks raises new possibilities for interpretation" (259-60). At the very least, Thorson's reading points out that is was "limestone" Thoreau throws out the window, and not simply rocks, and glosses limestone for us in a way that we may easily have missed. In countless examples, Thorson shows how, taken in by Thoreau's poetic, philosophical story, we may fail to see the geological one being told at the same time.

Thorson is more assertive about his re-interpretation of Thoreau's famous description, in the "Spring" chapter of Walden, of the foliage-like sand formations along the banks of the Fitchburg Railroad. Thorson helpfully traces how Thoreau reworked the passage through successive Journal entries from a more symbolic interpretation of the formations to a more geophysical one. The final Walden version reads: "There is 
nothing inorganic. These foliaceous heaps lie along the bank like the slag of a furnace, showing that nature is 'in full blast' within. The earth is not a mere fragment of dead history, stratum upon stratum, like the leaves of a book, to be studied by geologists and antiquaries chiefly, but living poetry, like the leaves of a tree, which precede flowers and fruit" (quoted 283). We might read the passage as saying poets not geologists have the greatest insight into the life of the sandbank. But Thorson reads the passage as Thoreau weighing in on the key debate in geology of his time, to argue for the geologists who understood the earth as active and alive-as "a slag of a furnace, showing that nature is 'in full blast"-and against those geologists who read the earth's rock layers as "fragments of dead" now inert, "history." Thorson excitedly concludes that "surely" Thoreau's revised passage must "target" the latter group. Again, whether you agree with Thorson's interpretations or not, the crash course his book offers in geology succeeds in getting us to reread Thoreau's writings with new eyes (281-85).

The first half of Thorson's study is appropriately called "The Place of the Book" and offers a scientific analysis of Walden's landscape; the second half, "The Book of the Place," offers a scientific interpretation of Walden. My examples of Thorson's close reading of the limestone and sand bank passages come from this second half. In the first half of his book, Thorson elucidates the geological foundations of the ecology in which Thoreau lived: on the chemical make-up of Sudbury River, for instance, we learn that "those same ions in the Thoreau household drinking water became the bones and teeth of the family and their boarders." After their deaths, their bones would "leach back into aquifers and streams" (63). Between the two halves of Thorson's book is a scientific "interlude" titled "The Walden System," which offers the most technical discussion of Walden Pond's make up, including the interworking of its four "realms": air, land, aquifer, and lake. Here as elsewhere Thorson takes us through his scientific material in a fascinating and accessible way. He illustrates his discussion with informative figures whose captions offer mini-courses in geology. Particularly valuable is Thorson's clarifying discussion of Thoreau's often, to a non-scientist's eye, cryptic sketches from his Journal of the natural processes he studies.

7 The logistics of Thorson's painstaking reconstruction of Thoreau's genealogies of thought are predictably complex and, sad to say, Thorson's text is, in places, a bit of a mess. Footnotes do not match quotes and typos alter dates so that his argument becomes difficult to follow. In his documenting of the evolution of the sand bank passage, for example, the year 1851 gets misrepresented by a typo as 1853, and in its footnote becomes 1981! A similar confusion happens in the scrambled footnotes to Thoreau's passage about the pieces of limestone, where sources for quotes appear under the wrong footnotes. The confusion is exacerbated by the fact that Thorson moves through multiple sources in a single paragraph, usually giving quotes without their authors. The reader is left to reconstruct the genealogy by referring frequently to Thorson's footnotes, and this becomes difficult when there are so many mistakes. Such proofreading errors become more significant given that Thorson's genealogies are central to his reinterpretation of Walden and Thoreau's development as a scientist.

Such problems do not distract significantly, however, from the many-layered contributions of Thorson's book. Thorson builds on Thoreau's "prescient" understanding of his region to show how it has been augmented by present day geoscience. We learn that Walden is not a single kettle pond, formed by an ice chunk left by a glacier, but four connected kettle ponds. We appreciate Thoreau's insight into 
his generation's environmental impact, but Thorson explains this in terms of our understanding today to show that it was in Thoreau's time that "Human beings bec[a]me the most important geological agent. The Anthropocene had arrived" (168). Proving again his talent for telling both science and stories, Thorson closes his book with a geological analysis of Thoreau's grave on a ridge of Sleepy Hollow Cemetery. Sleepy Hollow is, like Walden Pond, another kettle, only this time the kettle formed above, rather than below, the water table. Thorson argues that the final resting place of Thoreau's bones (all of him, as Thorson notes, that is now left) is particularly fitting: located on the ridge above the hollow, the grave site is comparable to the site Thoreau's cabin occupied on the shore of Walden Pond.

Robert Thorson's Walden's Shore is to my knowledge the first study by a research scientist to engage ecocritical studies of Thoreau with such care and depth. Over the course of the book, he debates in a refreshingly forthright way several points with ecocritics, including Laura Dassow Walls, whose work has been at the forefront of a humanist understanding of Thoreau and science. In places Thorson restates Walls' point, and simply says "Agreed" (239; 13). Other times he states his differing point of view: to Walls' claim that "Thoreau's artistry creates a fiction of wholeness...an eternal cycle of withdrawal and reunion," Thorson, who thinks Thoreau astutely perceived the organic cycles of life replies, "I do not see the fiction"(198). Through such constructive engagement, Thorson invites us to further discussion, clarification, and insight. Walden Shore offers a model of a science-humanities dialogue on which ultimately our appreciation of Thoreau's rich analysis of his world must depend.

\section{BIBLIOGRAPHY}

Works Cited

WALLS, Laura Dassow, Seeing New Worlds. Henry David Thoreau and Nineteenth Century Natural Science, Madison, University of Wisconsin Press, 1995.

\section{AUTHORS}

\section{SARAH LURIA}

College of the Holy Cross 